\title{
Mediation as an alternative method of conflict resolution: a practical approach
}

\author{
ANTONI BENEDIKT 1, A, B, D-F, ROBERT SUSŁO ${ }^{2, ~ D-F}$, MATEUSZ PAPLICKI 3, D, F, JAROSŁAW DROBNIK², A, D \\ $\begin{array}{lll}\text { ORCID ID: 0000-0003-2362-4409 ORCID ID: 0000-0002-2680-7617 'ORCID ID: 0000-0002-4169-9298 ORCID ID: 0000-0001-5472-1485 } & \end{array}$ \\ ${ }^{1}$ WSB University in Wroclaw, Poland \\ ${ }^{2}$ Gerontology Unit, Public Health Department, Faculty of Health Sciences, Wroclaw Medical University, Poland \\ ${ }^{3}$ Developmental Age Traumatology and Emergency Medicine Unit, Faculty of Medicine, Wroclaw Medical \\ University, Poland
}

A - Study Design, B - Data Collection, C - Statistical Analysis, D - Data Interpretation, E - Manuscript Preparation, F - Literature Search, G - Funds Collection

Summary Formal conflict resolutions are very familiar from media as legal trials resulting in long prison sentences or large compensation payments inevitably attract attention. In contrast, far more inconspicuous alternative dispute resolution (ADR) methods often demonstrate their great practical usefulness as conflicts between parties are not only inevitable, but can also be considered a positive phenomenon because conflict allows an unwanted situation to be changed to the benefit of all parties involved in a transaction. The second ADR thesis is that the parties on their own can resolve many, if not most, of their conflicts, but no ADR method can be effective when the parties have lost trust with each other. Mediation is probably the most popular ADR method in Poland presently as an intervention into negotiations or conflicts that are already underway. A third party, the mediator, who is accepted by all parties and does not possess any power to make an authoritative decision resolving the conflict, performs that intervention - aiding the parties to voluntarily reach a mutually acceptable solution to the conflict. Mediation is an attractive low-cost alternative to court proceedings as the parties remain in full control of the process, it is confidential, lasts short and allows conflicted parties to maintain their long-term relationship. Mediation may also limit the otherwise significant risk associated with the unpredictability of court rulings, especially in highly complicated medical malpractice-related cases. Results from any successful mediation become binding to the parties as courts legally approve the mediation agreement.

Key words: conflict, malpractice, medical errors, negotiating, dissent and disputes, jurisprudence.

Benedikt A, Susło R, Paplicki M, Drobnik J. Mediation as an alternative method of conflict resolution: a practical approach. Fam Med Prim Care Rev 2020; 22(3): 235-239, doi: https://doi.org/10.5114/fmpcr.2020.98252.

Conflicts are an unavoidable part of human life, and there are many formal and informal ways to resolve them. Formal resolutions are very familiar from media - legal trials resulting in long prison sentences or large compensation payments inevitably attract attention. However, informal methods of conflict resolution - though lower in profile and thus less familiar to the average person - possess a number of clear advantages.

\section{There are many conflicts involving medical professionals}

Discussions of conflicts involving medical professionals tend to focus predominantly on cases of medical malpractice, mainly negligence [1], that are often followed by legal actions in criminal and civil courts [2]. A medical mistake can involve any phase of complicated relations between medical professionals and patients, including: collecting consent for medical procedures [3]; health promotion and prevention of diseases [4]; diagnosis [5]; therapy [6]; rehabilitation; drawing up healthcare-related documents [7]; passing medical information [8]; and issuing medical opinions [9]. Quite often, an alleged medical mistake needs to be analyzed not only from the point of view of a particular medical professional who has made a questionable decision [10] but also include the organization of the decision-making process in the given medical care entity [11]. Generally, it is true: medical professionals often get sued but they sue - each other, their contractors or patients - as well. Consequently, there are many le- gal processes that could be avoided to the benefit of all involved parties - thank to alternative methods of conflict resolution.

In discussing mediation as an alternative method of conflict resolution, it is useful to start with an example: Jack is a 31 year-old employee working at a legal office, and Paul is a dentist who has run a private dental clinic for twenty years. Jack has been Paul's patient for the last sixteen years. Until recently, all their dental appointments went smoothly, and Jack had been very satisfied with the dental services provided by Paul. However, during Jack's last checkup, the dentist noticed that that his patient - who had been abroad for the previous year - had neglected regular dental care. As a result one of Jack's teeth had severely decayed. Paul applied a typical treatment, but in unfortunately this resulted in the tooth breaking under the gum. Paul informed Jack that, in line with modern dental procedures, the residual part of the root would have to be removed. A dental implant could be installed in its place at an estimated cost of about 6,000 PLN. Jack is outraged by the situation: it seems to him that the dentist has demonstrated a lack of professional competence and poor skills in dealing with the tooth and that, moreover, he is seeking a significant sum to resolve the problem he has created. Jack seriously considers suing Paul for significant compensation for what, to the distraught Jack, clearly seems to be a medical mistake. Paul is in turn angry at Jack: he is totally sure that the medical treatment was flawless, that the suggestion of an implant was justified, and that the price is fair. This outlines a relatively simple conflict situation rooted in a medical field. The basic question to be answered is how to resolve it. 
Before going down the path of hostile, expensive, and time-consuming legal actions - which will also almost inevitably end the long personal relationship between the two people - it may be reasonable for them to consider alternative methods of resolving the conflict, such as mediation.

\section{Alternative dispute resolution}

When a conflict seems likely to arise, natural psychological mechanisms are activated, including the urges to attack, defend, or escape. Typically these mechanisms active automatically but, in the modern world, the end results are not always satisfactory. In order to learn how to control them to our advantage, it is necessary to become aware of both the rules governing these mechanisms and the circumstances under which they can be used. It is also important to foresee the results of various methods of conflict resolution. Only by acquiring this knowledge and by training the relevant skills can strategies and methods of conduct be effectively shaped to deal with real conflicts.

In a conflict situation, alternative dispute resolution (ADR) methods demonstrate their great practical usefulness. The ADR approach relies on two basic theses: The first states that conflicts between parties are not only inevitable, but can also be a positive phenomenon of private, economic, and social life. This is the case because conflict allows an unwanted situation to be changed to the benefit of all parties involved in a transaction. A conflict situation turns into a sort of motivating agent that forces the parties to consider what needs to be done that so their relationship can evolve into one more satisfying to everyone.

The second thesis at the foundation of any ADR method is that the parties on their own can resolve many, if not most, of their conflicts. It should be clarified that not all conflicts can be resolved this way: no ADR method can be effective when the parties have lost trust with each other; it makes no sense to use an ADR method under such conditions. If there is a conflict between two neighboring farmers where one is alleged to have ploughed and planted their boundary strip, ADR can be used until the point where one of the farmers tells the other that there is no more point in talking and that he is taking him to court. On the other hand, if they are both aware that there is a conflict situation that requires resolution, but they are unable to resolve it satisfactorily on their own, then there is still a space in which ADR can be attempted.

In other words, the belief underlying ADR methods is that resolving the conflict in a way where all parties agree that the solution is correct constitutes the best guarantee that the agreement will be followed and that the source of the conflict will be removed, allowing smooth cooperation in future. It should also be mentioned that this approach to conflict resolution is also relatively rapid and low cost [12].

\section{Characteristics of mediation and of media- tors}

Mediation is probably the most popular ADR method in Poland presently. In most cases, being a mediator means acting as a go-between for two or more parties who are seeking a common solution to a conflict. A more precise definition comes from Christopher W. Moore, who states that mediation [13]:

- is an intervention into negotiations or conflicts that are already underway;

- is performed by a third party, the mediator, who is accepted by all parties;

- does not make use of a mediator with the power to make an authoritative decision resolving the conflict;

- involves a mediator whose role is to aid the parties to voluntarily reach a mutually acceptable solution to the conflict.
The mediator is thus a person who is not directly involved in the conflict, who remains impartial, who possesses skills that help channel the conflict situation without interfering in the agreement. The parties are the ones who are supposed to make commitments to each other and to bear the responsibility to fulfill them. The duties of the mediator are as follows:

- to facilitate communication between the parties;

- $\quad$ to make the parties aware of their rights;

- $\quad$ to provide the parties with knowledge of techniques that may help in resolving the conflict;

- $\quad$ to chair the sessions formally;

- to educate the parties when needed;

- to help the parties explore various aspects of the conflict;

- to verify the feasibility of proposed solutions;

- to expand the parties' understanding of the conflict by contacting experts in the appropriate field;

- $\quad$ and to initiate and conduct the negotiations.

Neutrality is the mediation's first key value. The mediator is not involved in the conflict directly, but is instead a go-between; he or she helps resolve the conflict by finding an optimal solution acceptable to the interests of all the parties.

The second cornerstone of mediation is the belief that it is possible to reconcile the conflicted parties without the external and arbitrary intervention of a court. In this context, the great practical use of the ADR approach can be observed particularly often in the field of family law, especially in cases concerning custody or division of estates.

Unlike contrary a conciliator or an arbitrator, a mediator does not provide the conflicted parties with a proposed solution that they could accept, reject, or be bound by. Mediation instead demands from the parties that they become involved in the process of finding a solution and accepting responsibility for its results; the mediator's role is mainly to control the flow of that process. On average, formal mediation proceedings take three to ten sessions, during which the parties are supposed to suggest deals. The deal proposals are subject to the mediator's supervision and, when needed, to correction under the mediator's guidance.

According to Sylwester Pieckowski, the term "mediation" has remained undefined in both international and local law. Both the praxis and theory of mediation describe this method as a process of resolving conflicts in which the parties discuss the causes of the conflict with the aim of reaching an agreement, while being supported by one or more mediators. The American ADR expert Don Peters suggests that mediation be interpreted as aided negotiations and that such negotiations constitute the most common proceedings used to build legal arrangements and solve conflicts.

\section{Styles of mediation}

Mediation is intended to assist the conflicted parties to reach a mutually acceptable and beneficial solution. It therefore involves deep and insightful consideration of all causes of the conflict, as well as a creative quest for solutions that may prove satisfying for all parties. Each mediation process is unique in its characteristics, so there is no uniform mediation methodology. There are also many mediation styles described in the literature, of which the most popular are facilitative mediation and evaluative mediation.

Facilitative mediation, also known as conciliation or facilitation, assumes that the mediator is supposed to refrain from expressing any opinion that concerns the core of the conflict and ways to resolve it. Consequently, the mediator's entire activity is focused on improving the process conflict resolution. This can be aided by making the parties familiar with efficient interpersonal communication techniques, eliminating negative emotions, and supporting the parties in determining their interests 
and defining their stances. In other words, facilitative mediation is typically a process in a third party assists the parties to come to an agreement that solves their problem. Here the mediator - also called the conciliator or facilitator - does not take a direct part in the process of arranging it, but instead mainly acts to reduce tensions between the parties and to monitor and organize their communication, especially with the aim of eliminating rhetoric that may kindle the conflict. The modern literature increasingly takes mediation to encompass conciliation.

Evaluative mediation can be described in opposition to facilitative mediation. Here, the mediator does not hesitate to disclose to the conflicted parties his or her views on the core of the problem, or even to draw an outline of a solution. This mediation style is quite popular among mediators in Warsaw.

It should be stressed, however, that both of these mediation styles may be applied to various extents by the mediator in any given case, depending on his or her personal preferences and focus on the parties' aims and desires. An important role is also played by the mediator's evaluation of the parties' ability to cooperate in the process and to find the solution independently. In any case, the parties remain in full control of the mediation process; among other factors, this means they retain the right to choose a given mediator, as well as stop availing of his or her services.

\section{Mediation: fields of application}

Mediation has gained, and continues to gain, popularity mainly because it is relatively fast, frugal, and uncomplicated. In comparison to typical legal proceedings, mediation is also more confidential, as there is no role for arbitrarily assigned third parties or the public.

Typical applications of mediation include [13]:

- family conflicts (e.g., over methods of upbringing or violence);

- divorce conflicts (e.g., over alimony or custody rights);

- residential conflicts (e.g., over rent prices);

- environmental conflicts (e.g., over the location of a new industrial plant);

- workplace conflicts (e.g., over employer-employee tensions or those between employees);

- transportation conflicts (e.g., over bus timetables);

- conflicts in international politics (e.g., over tensions between states);

- conflicts in municipal politics (e.g., over changes in urban architecture plans or the sale of municipal properties);
- $\quad$ school conflicts (e.g., over tensions between pupils);

- ethnic conflicts;

- judiciary conflicts (e.g., over compensation amounts).

In theory, there is no conflict that cannot be solved by mediation. However, mediation is a voluntary process, so all parties need to be willing to participate in it. The basis for any mediation is thus obtained a clear declaration of consent from all the parties in the conflict.

In the case of organizations, mediation can be applied to bath external and internal conflicts. External conflicts are those that arise when deals are being made and when they are being fulfilled. On the other hand, internal conflicts concern relations among the various entities that comprise the organization.

Based on the experiences from countries where mediation is much more popular than in Poland, it is commonly applied to conflicts in the following areas:

- international agreements;

- fulfillment of long-term contracts, especially in construction;

- company rescue, receivership, and bankruptcy proceedings:

- responsibilities of manufacturers and of independent professionals, including physicians and dentists.

\section{Clear strengths of mediation}

The use of mediation is tempting especially in conflicts where time is of the essence. The low cost of mediation proceedings make then an attractive alternative to court proceedings. Mediation is profitable for conflicted parties who are striving to maintain their long-term relationship, as well for those for whom confidentiality is a priority. Mediation may also limit the otherwise significant risk associated with the unpredictability of court rulings in highly complicated cases. The advantages of mediation over other common means of resolving conflicts are summarized in Table 1 [14].

\section{Practical approaches to mediation}

Typically, participating in mediation effectively requires some preparation. It is done best as a conscious and organized process, like the one structured into the Harvard negotiations model, which was created in the 1990s as an aid to solving conflicts in profession-related fields, in order to use a negotiation style that is matter-of-fact and just, while avoiding manipulation and coercion. The main rules of the model are as follows:

\begin{tabular}{|c|c|c|c|}
\hline & Mediation & Court proceedings & Arbitration \\
\hline Financial cost & Very low & Very high & High \\
\hline Time & $\begin{array}{l}\text { Typically very short (several } \\
\text { weeks) }\end{array}$ & $\begin{array}{l}\text { Typically very long (several } \\
\text { years) }\end{array}$ & Typically long (several months) \\
\hline Who makes decision? & The parties & The judge or the jury & Arbiter \\
\hline Who controls the proceedings? & The parties & Legal professionals & Legal professionals \\
\hline Rules of providing evidence & None & Highly formalized & Partially formalized \\
\hline Confidentiality & Full & $\begin{array}{l}\text { None or arbitrarily limited by } \\
\text { a third party }\end{array}$ & Full \\
\hline Focus & Future & Past & Past \\
\hline $\begin{array}{l}\text { Communication among con- } \\
\text { flicted parties }\end{array}$ & Intense & None & Limited \\
\hline $\begin{array}{l}\text { Issues associated with jurisdic- } \\
\text { tion }\end{array}$ & None & Present & Sometimes present \\
\hline $\begin{array}{l}\text { Average level of satisfaction of } \\
\text { all conflicted parties }\end{array}$ & High & Very low & Low \\
\hline Result & Win-win & Win-lose & Win-lose \\
\hline Tension & Stress is relieved & Stress continues & Stress continues \\
\hline
\end{tabular}


1) separate the people from the problem;

2) concentrate on interests, not on people's stances;

3) aim at solution that is satisfying and beneficial to all parties;

4) the solution should be reached based on neutral and objective criteria.

The first rule of separating the people from the problem has many aspects. Above all, conflicted parties should be constantly aware that in the negotiations they are dealing with people - who are directed by values and feelings - and not with computers whose moves can be foreseen based on a logical algorithm governing their actions. At one moment people perceive themselves positively and expect to be acknowledged by others, while at other times they may be frustrated, stressed, or agitated, and thus likely to interpret everything as a personal attack or criticism. Overlooking such subjective factors often leads to negotiation disaster.

The second aspect of the first rule is that the merit of the current mediation and of maintaining good personal relationships between the parties should be considered to be of equal importance, especially as many mediations involve parties who have already developed a long-term relationship is expected to be lasting.

From the first rule, we can also derive the need to separate personal prejudices, biases, and aversions from merit. Typically, problems arise during mediation not purely because of merit, but because of imaginations that the parties continue nurturing. For this reason, in order to succeed in the mediation process, it is often more important to understand the parties' ideas of the conflict, and sometimes to empathize with their situation and views, than to understand the issue itself. The behaviors of the parties should be interpreted objectively, with neither bravado nor exaggerated fears.

The first rule also means that accusations and objections that are not constructive, and which might only block the other parties in their positions, should be avoided. Frustration resulting from unfavorable status needs to be separated from attitudes towards the people involved in the case; this can help limit the vicious circle of negative communicates and thus facilitating valuable communication.

It should be stressed that the points of view of the conflicted parties may be strikingly different. A vivid example might be the case of a patient whose dentist is considering increasing the price of treatment; this is outlined in Table 2 [15].

Table 2. Example of differing points of view of the conflicted
parties

Emotional sensitivity is useful during mediation, as it is extremely easy to focus merely on the points being made without considering the emotions involved. Tactfully informing another party about perceived emotions is likely to facilitate the whole process, as only after liberating the emotions can truly efficient work towards the solution become possible.
Responding to provocations during mediation should be avoided. If a mistake occurs, a polite apology to the parties affected can clear the atmosphere and reestablish effective communication. Active listening and sending feedback to other parties is advisable as a means of avoiding misunderstanding. In order to help the other parties better understand one's subjective view of an issue, a "me" perspective should be preferred to a "you" perspective in communication; however, as it is impossible to properly clarify something to others before it is clarified to ourselves, one's own aims should be clearly defined prior to entering the mediation session. Creating positive informal and personal relationships between representatives of organizations who are parties to the mediation often facilitates the process.

The second rule of the Harvard negotiations model advises those involved to concentrate on interests, not on people's stances. The fundamental problem in mediation, after all, is the conflict of interests, and not the differing stances of people. Consequently, it is crucial to remember during mediation that conflicting interests are the basis for people's differing stances and the decisions resulting from them, and not the other way around.

An interest can typically be satisfied by assuming more than one stance. Moreover, in the vast majority of mediations, the conflicted parties have more common than differing interests. It is worth remembering Maslow's hierarchy of human needs, classically portrayed in the shape of a pyramid with the more basic needs at the bottom. The needs it enumerates are physiological needs, safety needs, social belonging, self-esteem, and self-actualization; it is a general rule that a need can only be satisfied once all the needs below it in the hierarchy have already been satisfied.

The third rule of the Harvard negotiations model suggests aiming for solutions that are satisfying and beneficial to all parties. It is important to follow this rule as the proposals of the other conflicted party are often seen very critically. At the same time, rigidly limiting consideration to a single preferred option is likely to interrupt the process, which could otherwise lead to more options that are acceptable to multiple parties. Besides, focusing only on one's own positions and propositions makes progress virtually impossible in mediation, as in such a scenario each party would stick to only its own position and not budge.

The fourth rule of the Harvard negotiations model states that the solution of the conflict should be reached based on neutral and objective criteria that are independent of the will of the mediating parties. Only this approach allows success in mediation of the common situation where not all the interests of all the conflicted parties can be satisfied, even assuming that full mutual understanding is reached.

\section{Weaknesses of mediation}

There is no ideal method of resolving conflicts, and this includes mediation. Among the main weaknesses of mediation is the risk associated with the lack of balance of strength among conflicted parties; where there is a significant asymmetry in the parties' economic or intellectual resources, the stronger party is likely to abuse its favorable position. This can be, at least partially, remedied by systemic mechanisms of the legal system of the modern state that define standards of mediation proceedings and mediator selection, enforce an ethical code for mediators, and ensure their professional training; also crucial is the role of the courts that legally approve the mediation agreement that results from any successful mediation.

One allegation sometimes held against mediation is that it is a tool for the privatization of the justice system, stripping the state and its courts of their competences. However, this would seem to be a reasonable price for the humanization of interpersonal relationships, empowering citizens and migrating from a culture of confrontation and conflict towards a culture of dialogue and agreement. 
Another issue raised critically in the context of mediation is the risk of increasing costs and lengthening time of conflict resolution if mediation fails and the parties need to enter court proceedings or arbitrage. In fact, this is not the correct point of view of this problem: it is widely known that typical court proceedings, and even arbitrage, are very expensive take a great deal of time. Both of these burdens can be avoided through successful mediation. The true problem is rather how to make mediation successful. A positive outcome of mediation becomes highly likely of the conflicted parties enter the process freely, without being coerced to do so in any way, and if not only the nature of the conflict but also the nature of the relationships between the parties allow the mediation process to be properly run by the mediator.

\section{Conclusions}

The medical environment is rich in opportunities for various conflicts to arise, with increasingly common allegations of medical incompetence being made, resulting in demands for significant financial compensation. Given the pros and cons of mediation, it is clear that this method is a highly valuable method of resolving conflicts in an inexpensive, timely, and mutually respectful way that also allows continuing cooperation in the future.

Source of funding: This work was funded from the authors' own resources.

Conflicts of interest: The authors declare no conflicts of interest.

\section{References}

1. Trnka J, Drobnik J, Susło R, et al. Staranność i rzetelność a lekkomyślność i niedbalstwo w pracy lekarza rodzinnego. Przew Lek 2008; 1: 265-269 (in Polish).

2. Trnka J, Susło R, Drobnik J, et al. Rodzaje odpowiedzialności lekarza za błędy medyczne i ich praktyczne następstwa. Fam Med Prim Care Rev 2009; 11(3): 783-785 (in Polish).

3. Drobnik J, Trnka J, Susło R. Ambushes related to collecting patients' consent for medical procedures by family doctors. Fam Med Prim Care Rev 2017; 19(3): 298-302, doi: https://doi.org/10.5114/fmpcr.2017.69294.

4. Paplicki M, Susło R, Najjar N, et al. Conflict of individual freedom and community health safety: legal conditions on mandatory vaccinations and changes in the judicial approach in the case of avoidance. Fam Med Prim Care Rev 2018; 20(4): 389-395, doi: https://doi. org/10.5114/fmpcr.2018.80081.

5. Trnka J, Susło R, Drobnik J, et al. Pojęcie błędu diagnostycznego we współczesnej medycynie. Fam Med Prim Care Rev 2009; 11(3): 788-789 (in Polish).

6. Trnka J, Susło R, Drobnik J, et al. Możliwości popełnienia błędu terapeutycznego na różnych etapach postępowania z pacjentem. Fam Med Prim Care Rev 2009; 11(3): 786-787 (in Polish).

7. Drobnik J, Trnka J, Susło R, et al. Zagrożenie błędem medycznym formalnym w praktyce lekarza rodzinnego. Fam Med Prim Care Rev 2009; 11(3): 590-592 (in Polish).

8. Drobnik J, Trnka J, Susło R, et al. Nowa kategoria błędu medycznego - błąd informacyjny. Fam Med Prim Care Rev 2009; 11(3): 593-594 (in Polish).

9. Susło R, Trnka J, Drobnik J, et al. Sposób sporządzania dokumentów medycznych jako przyczyna błędu opiniodawczego. Fam Med Prim Care Rev 2009; 11(3): 506-508 (in Polish).

10. Trnka J, Susło R, Drobnik J, et al. Okoliczności sprzyjające wystąpieniu medycznych błędów decyzyjnych. Fam Med Prim Care Rev 2009; 11(3): 781-782 (in Polish).

11. Drobnik J, Susło R, Trnka J, et al. Błąd organizacyjny jako wynik braku optymalizacji funkcjonowania placówek opieki medycznej. Fam Med Prim Care Rev 2009; 11(3): 287-289 (in Polish).

12. Morek R. ADR - w sprawach gospodarczych. Warszawa: Wydawnictwo C.H. Beck; 2004 (in Polish).

13. Haeske U. Konflikty w życiu zawodowym. Mediacja i trening w rozwiqzywaniu problemów. Kielce: Wydawnictwo Jedność; 2005 (in Polish).

14. Pieckowski S. Mediacja w sprawach cywilnych. Warszawa: Wydawnictwo Difin; 2006 (in Polish).

15. Fisher R, Ury W, Patton B. Dochodzqc do tak. Negocjowanie bez poddawania się. Warszawa: Polskie Wydawnictwo Ekonomiczne; 2004 (in Polish).

Tables: 2

Figures: 0

References: 15

Received: 19.08.2019

Reviewed: 27.09.2019

Accepted: 11.05 .2020

Address for correspondence:

Robert Susło, MD, PhD, MA

Zakład Gerontologii

Katedra Zdrowia Publicznego

Wydział Nauk o Zdrowiu

Uniwersytet Medyczny we Wrocławiu

ul. Bartla 5

51-618 Wrocław

Polska

Tel.: +48 71 345-93-24

E-mail: robert.suslo@umed.wroc.pl 